Ю. В. Ткаченко

\title{
ПРЕФІКСАЛЬНО-ПОСТФІКСАЛЬНІ ФОРМАНТИ ЯК ЗАСІБ ВИРАЖЕННЯ ГРАДУАЛЬНОГО ЗНАЧЕННЯ ДІЕСЛІВ В УКРАЇНСЬКІЙ МОВІ
}

Ткаченко Ю. В. Префіксально-постфіксальні форманти як засіб вираження градуального значення дієслів в українській мові.

Стаття присвячена дослідженню префіксально-постфіксальних формантів на- + -ся, ви- + -ся, до- + -ся, з-(с-) + -ся, у-(в-) + -ся, об-(обі-) + -ся, за- + -ся, роз-(розі-) + -ся, при- + -ся як засобів вираження градації в сучасній українській мові. Проаналізовано лексеми 3 вищезазначеними формантами та визначено грандвідтінки, які вони вносять у семантичну структуру слова.

Ключові слова: словотворчий формант, градосема, градуальна функція, градуальність, градуатор, гранд-відтінок.

Ткаченко Ю. В. Префиксально-постфиксальные форманты как способ выражения градации в современном украинском языке.

Статья посвящена исследованию префиксально-постфиксальных формантов на+ -ся, ви- + -ся, до- + -ся, з-(с-) + -ся, у-(в-) + -ся, об-(обі-) + -ся, за- + -ся, роз- (розі-) + -ся, при- + -ся с помощью которых выражается градация в современном украинском языке. Проанализировано лексемы с вышеназванными формантами и определено гранд-оттенки, которые они вносят в семантическую структуру слова.

Ключевые слова: словообразовательные форманты, градосема, градуальная функция, градация, градуатор, гранд-оттенок.

Tkachenko Y. V. Prefixal and postfixal parts as way of expression the matter of degrees meaning of the verbs in Ukrainian language.

The article is devoted to research of detachable -postfixsalnyh formats on- + sia, vy, + sia, do- + - sia, z(s), - sia, u, -(v) + sia,ob, (obi) +sia, za-, sia, roz-(rozi) + sia, pry, + sia. As means of expression of gradation in modern Ukrainian. Lexems are anylysed with the above mentioned formants and certainly grandee of tint that bring in the semantic structure of word.

Key words: word-formation format gradosema, gradation (graduactor), grandee tint.

Словотворчі засоби вираження градуального значення $\epsilon$ набором афіксів, поєднаних парадигматичними відношеннями. Афікси розрізняються за продуктивністю, дистрибуцією й додатковим значенням, яке вони передають, будучи об'єднаними загальним словотворчим значенням поля градації. Градуальний компонент (афікс) вносить градосему, що співвідноситься 3 семантичним полем якісної ознаки. Словотворення є одним із найпродуктивніших способів вираження градуального значення [4]. Градуальність дієслова може бути передана за допомогою префіксально-постфіксальних формантів, які вносять у лексему різноманітні семантичні відтінки.

Мета статті - розглянути префіксально-постфіксальні форманти на- + -ся, ви- + -ся, до- + -ся, з-(с-) + -ся, у-(в-) + -ся, об-(обі-) + -ся, за- + -ся, роз-(розі-) + -ся, при- + -ся як засіб вираження градації в сучасній (C) Ю. В. Ткаченко, 2013. 
українській мові; проаналізувати лексеми з вищеназваними формантами та визначити гранд-відтінки, які вони вносять у семантичну структуру слова.

Словотворення дієслів за допомогою форманта на- + -ся $\epsilon$ найпродуктивнішим префіксально-постфіксальним способом вираження градуального значення. Вищезазначений формант, вказуючи на високий ступінь вияву ознаки дії, виражає значення задоволення або незадоволення діяча дією. А. Ісаченко називає такий спосіб дії сатуративним [3]. Дієслова, утворені префіксально-постфіксальним способом за допомогою форманта на- + -ся, вказують на чисельність як міру вияву ознаки дії.

Дієслова зі значенням сатуративності (результат довготривалої i повторюваної дії) виражають відтінок задоволення або незадоволення. Префікс на- і постфікс -ся, приєднуючись до дієслів недоконаного виду, виконує градуальну функцію, оскільки вносять у їх семантичну структуру гранд-відтінок - інтенсивний вияв ознаки дії. Лексеми з відтінком задоволення навечерятися, напитися, наспатися, напастися, насититися об'єднані спільною градосемою «досхочу». Наприклад, дієслово навечерятися означає «наїстися під час вечері» [5, с. 250]; - Tu, голубе, ще в обід навечерявся (М. Павленко); напитися - «пити що-небудь, угамовуючи спрагу» [5, с. 290]; Іде святий Петро Та, йдучи в Рим благовістити, Зайиов у гай води напитись I одпочити (Т. Шевченко); наспатися - «спати багато» [5, с. 304]; насититися - «задовольняти потребу в їжі; наїдатися вволю» [5, с. 304]; Коли всі наситилися, дідусь зібрав усі дрібки і недоїдки і виніс перед хату (I. Франко); напастися - «жадібно накидатися на що-небудь їстівне» [5, с. 289]; Горобиі налетіли з садка і напаслись на пшениц̧і (І. Нечуй-Левицький).

Лексеми набігатися, наслухатися, виражаючи високий ступінь вияву ознаки дії, об’єднані спільною градосемою «уволю». Наприклад, дієслово набігатися означає «побігати до втоми» [5, с. 247]; - Набігаєшся, наганяєшся за цілий день - а ввечері спать хочеться (П. Мирний); наслухатися - «почути, послухати багато чого-небудь або про кого-, щонебудь» [5, с. 307]; Він тілько наслухався про неї [гадюку] всякої страховини, $i$ як вона кусається, і як сичить, і яка страшна-страшна (П. Мирний).

У лексемі настоятися виділяємо градосему «удосталь»: настоятися «утворювати, давати настій, настойку» [5, с. 311]; Вже й чай настоявся. Ватя поналивала (І. Нечуй-Левицький).

У дієсловах доконаного виду 3 префіксом на- і постфіксом -ся, які виражають неприємні відчуття, незадоволеність діяча дією, сатуративний відтінок розуміємо як інтенсивний вияв ознаки дії, доведений до крайності (вище норми). Лексеми напитися, наклюватися, наплакатися, настраљсдатися, натерпітися об'єднані спільною градосемою «занадто». Наприклад, дієслово напитися означає «уживаючи спиртні напої, ставати п'яним; упиватися» [5, с. 290]; А прийде ввечері товариство... Наӥдяться, нап'ються, погуляють, - та й з двору, й Чіпка з ними! (П. Мирний); наклюватися - 
«багато клюючи, дуже наїдатися (про птахів)» [5, с. 278]; Курка наклюється латаття та здохне (П. Мирний); наплакатися - «багато плакати» [5, с. 291]; Наплакався [кобзар]. Струни рвані Три перебирає (Т. Шевченко); настраждатися - «зазнати багато страждань» [5, с. 311]; натерпітися «зазнати, перенести багато тяжкого, неприємного; настраждатися, набідуватися» [5, с. 314]; - Прийду було ї̈ [панночку] вбирати, то вже якої наруги я од неї не натерплюся! (Марко Вовчок).

Значення вичерпності дії вносить у лексему префіксальнопостфіксальний формант ви- + -ся, приєднуючись до дієслів недоконаного виду. Сатуративне значення виражають дієслова доконаного виду 3 вищевказаним формантом, оскільки дія відбувається вповні упродовж певного проміжку часу. Дієсловам 3 префіксом ви- і постфіксом -ся притаманна градуальність, бо вищезазначені форманти вносять у лексему грандвідтінок - інтенсивний вияв ознаки дії (вище зв норму). У семантичній структурі лексем вивалятися, виговоритися, вигрітися, вигулятися, видивитися, виплакатися, виспатися, виспіватися, витанцюватися виділяємо спільну градосему «удосталь». Наприклад, дієслово вивалятися означає «довго пробути в постелі, у ліжку» [5, с. 193]; Два тижні вивалявся я тоді в ліжку $i$ як ото дуба не дав - $i$ сам не розумію (Б. Антоненко-Давидович); виговоритися - «говорити досхочу, розповідати, висловлювати все» [5, с. 199]; вигрітися - «грітися протягом певного часу, одержуючи, маючи достатню кількість тепла» [5, с. 201]; 3 води біжить на пісок, щзоб вигрітися (I. Нечуй-Левицький); вигулясться - «розм. гуляти довго, досхочу, виходжуватися» [5, с. 201]; - Ляже не клята, встане не м'ята, наїсться, нап 'ється, вигулясться, так чому ж їй не бути хорошою (С. Васильченко); видивитися - «втупивши очі, дуже пильно й уважно дивитися» [5, с. 204]; Вояк витріщеними очима видивився на Спориша, як на чоловіка, у якого не всі дома (І. Франко); виплакатися - «плакати досхочу, до заспокоєння» [5, с. 233]; Фрузя виплакалася, і ій зробилося легше (І. Франко); виспатися «спати довго, досхочу, цілком задовольняючи потребу у сні» [5, с. 246]; Лягай раніше, виспися, - каже їй хазяйка (П. Мирний); виспіватися «виливати, передавати свої почуття в пісні, співові» [5, с. 254]; - Мені було так тяжко на душі... я мусила виспіватися! (Н. Кобринська); витанцюватися «багато танцюючи, витрачати всі сили» [5, с. 259]; Одарка береться в боки, починає танџювати. Картя дивиться на неї, сміється. Одарка спиняється. [Катря] Ну, вже витанцювалась? (С. Васильченко).

Дієслова вибілитися, виваритися, виголодатися, вилікуватися, вимочитися, виродитися об'єднує спільна градосема «повністю». Наприклад, лексема вибілитися означає «білішати під інтенсивною дією сонця (про людину, її волосся і т. ін.)» [5, с. 191]; Роздобріла Марина, вибілилася, мов та панянка (П. Мирний); виваритися - «довго варячись, втрачати смакові або поживні якості» [5, с. 194]; виголодатися - «ставати голодним; терпіти () Ю. В. Ткаченко, 2013. 
голод, виголоднітися» [5, с. 200]; Було $i$ змерзне [хлопчик], i виголодається, $a$ мовчить, терпить, аби тільки з батьком бути (О. Стороженко); вилікуватися - «лікуючись, позбавлятися хвороби, недуги; робитися здоровим, видужати» [5, с. 219]; вимочитися - «робитися дуже мокрим» [5, с. 225]; Вимочився я так у воді добре, поки на березі моє шмаття не висохло (І. Франко); виродитися - «перетворюватися в кого-небудь гіршого, у щось гірше» [5, с. 242]; Ми вели б неустанну боротьбу між собою, котра остаточно мусила виродитися у ненависть (Н. Кобринська).

Конфікс до-...-ся $\epsilon$ формальним показником фінально-досяжного способу дієслівної дії. «Домінантна функція префікса до- - позначення межі у вияві дії» [2, с. 46]. О. Добрушина зазначає, що «префіксальний формант до- відображає ідею дистанції між якимось моментом дії та їі результатом, а постфікс -ся акцентує увагу на дії суб'єкта, «віддаляючи» того, на кого спрямована реалізація дії» [1, с. 49].

Продуктивний словотворчий формант до- + -ся, приєднуючись до дієслів недоконаного виду і не змінюючи загального лексичного значення, вносить у їх семантичну структуру гранд-відтінок - доведення дії до певної мети, до певного етапу в результаті довгих інтенсивних зусиль. Дієслова додзвонитися, докричатися, доколупатися, докоситися, долікуватися, донюхатися, допитатися, допроситися, допхатися, дорозумітися, доучитися, доховатися об'єднані спільною градосемою «повністю, остаточно, до кінця». Наприклад, дієслово додзвонитися означає «дзвонячи, домагатися відповіді» [5, с. 575]; - Сидите изілий день у себе в хаті-не додзвониися вас! (Леся Українка); докричатися - «довго кричачи, домогтися того, щоб хто-небудь почув, відгукнувся; докликатися» [5, с. 580]; доколупатися - «колупаючись, добиратися до чого-небудь, наближатися до певної межі» [5, с. 579]; Доколупався до самої землі (І.Франко); докоситися - «косячи, досягати якого-небудь місця, певної межі» [5, с. 580]; допитатися - «настійливо розпитуючи, вивідувати щось, дізнаватися про що-небудь» [5, с. 589]; допроситися - «настійливими просьбами домагатися чого-небудь» [5, с. 591]; допхатися - «3 труднощами дістатися, добратися куди-небудь, до якогонебудь місця» [5, с. 591]; Маланка ледве допхалась до своєї халупки (М. Коцюбинський); дочекатися - «пробути, прожити до того часу, поки настане, з'явиться очікуване; діждатися» [5, с. 604]; Хочеться швидие дочекатися літа (М. Коцюбинський); дошукатися - «наполегливо шукаючи, намагатися знайти кого-, що-небудь» [5, с. 606].

У семантичній структурі дієслів доконаного виду префікс до- і постфікс -ся виражають значення «вияв дії в результаті інтенсивних зусиль, що приводить до негативних наслідків». Лексеми добалакатися, доборотися, добрехатися, довертітися, догулятися, докуритися, дострибатися, достоятися об'єднані спільною семою «понад міру». Наприклад, дієслово добалакатися означає «багато балакаючи, зазнавати лиха» [5, с. 561]; 
І добалакались... Надвечір лихо склалось: Страшенна буря зразу заревла. Змагався довго Дуб, стогнав, не подавався, А далі затріщав, зломився $i-$ упав... (Л. Глібов); доборотися - «боротьбою за що-небудь дійти до якихось неприємних наслідків» [5, с. 563]; Доборолась Україна До самого краю. Гірше ляха свої діти Ї̈ розпинають (Т. Шевченко); добрехатися - «багато брешучи, зазнавати чого-небудь небажаного, неприємного» [5, с. 564]; Брешіть, брешіть, воріженьки, Добрешетесь лиха (Укр. лір. пісні); довертітися - «хитруючи, зазнавати чого-небудь небажаного, неприємного» [5, с. 570]; - А що, взяв? Вертів, вертів хвостом, бісів Супруненко, та й довертівся! Так вам і треба, гаспидські дуки! (П. Мирний); догулятися «багато гуляючи, зазнавати неприємностей» [5, с. 574]; Догулявся чумачина, Що й копочки нема (М. Кропивницький); докуритися - «курячи (перв. надмірно), зазнавати чого-небудь небажаного, неприємного» [5, с. 581]; [Павло:] Ще вчора докурився дощенту, така нудьга обгорнула, щзо мало не здурів (М. Кропивницький); допитися - «надмірно п’ючи спиртне, зазнавати чогось небажаного, неприємного» [5, с. 588].

Префіксально-постфіксальний формант до- + -ся в дієслові доторкнутися вказує на низький ступінь вияву ознаки дії. У семантичній структурі вищезазначеної лексеми виділяємо градосему «злегка» (нижче за норму): доторкнутися - «торкатися до кого-, чого-небудь; приторкатися» [5, с. 601]; Він доторкнувся до неї пальцями ... (I. Франко).

Отже, префіксально-постфіксальний формант до- + -ся в дієслівних лексемах доконаного виду є засобом вираження градуального значення.

Також засобом вираження градуальності $є$ префікс з- (с-) і постфікс -ся, оскільки, приєднуючись до дієслів, вносять у їх семантичну структуру значення «доведення дії до небажаного стану (втоми тощо) унаслідок вияву інтенсивної дії, яка відбувається впродовж певного проміжку часу». Дієслова змучитися, стомитися, знервуватися об'єднує спільна градосема «дуже»: змучитися - «утрачаючи сили, виснажуватися фізично» [5, с. 770]; стомитися - «зазнавати втоми; натомлюватися» [5, с. 441]; знервуватися «перебувати у стані нервового збудження, хвилювання» [5, с. 773].

Префікс по- і постфікс -ся, виконуючи градуальну функцію, вносять у семантичну структуру дієслів гранд-відтінок - інтенсивний вияв ознаки дії (вище за норму). Дісслова побиватися, помішатися, потішатися мають спільну градосему «занадто». Наприклад, дієслово побиватися означає «дуже тужити, нудьгувати, жалкувати за ким-, чим-небудь; переживати через кого-, що-небудь» [5, с. 704]; Чи можем ми, діти, веселими бути, Як ненька в недолі, в нужді побивається нами? (Леся Українка); помішатися - «стати психічно ненормальним, збожеволіти» [5, с. 790]; Еней од страху з плигу збився, В умі сердега помішавсь $і$ зараз сам не свій зробився, Скакав, вертівся $і$ качавсь (І. Котляревський); потішатися «знаходити в кому-, чому-небудь задоволення, радість; тішитися» [5, с. 842]; ○ Ю. В. Ткаченко, 2013. 
Се та Оксана, щзо була їи радість $i$ втіха $i$ щзо єю [нею] мати потішалась $і$ величалась!.. (Гр. Квітка-Основ'яненко).

Інтенсивний вияв ознаки дії в дієсловах доконаного виду передає префіксально-постфіксальний формант у-(в-) + -ся, а отже, він, виконуючи градуальну функцію, $є$ засобом вираження градуальності. Дієслова уморитися, вбитися, упитися об'єднані спільною семою «надто». Наприклад, лексема уморитися означає «дуже стомитися, змучитися» [5, с. 619]; вбитися - «позбавляти себе життя вогнепальною або холодною зброєю і т. ін.» [5, с. 596]; - I він один на всім світі, Один мене любить; А почує, щуо я вбилась, То й себе погубить (Т. Шевченко); упитися - «п'ючи вино, горілку і т. ін., п'яніти, ставати п'яним» [5, с. 622]; 3 того часу щзовечір вона була й n'яна; а вирве вдень годинку, то і вдень уп'ється (Марко Вовчок).

Дієслова з префіксом в- і постфіксом -ся мають значення «заглибитися, вникнути в що-небудь внаслідок інтенсивної дії». Лексеми вдуматися, вдивитися, впитися, впертися, вп 'ястися мають спільну градосему «дуже». Наприклад, дієслово вдуматися означає «серйозно, зосереджено думаючи, вникати, заглиблюватися в суть чого-небудь» [5, с. 172]; Вдумався в тоту історію $i$ побачив, щзо все се була підла, огидна інтрига ї̈ братів (I. Франко); вдивитися - «пильно, уважно дивитися кудись, на кого-, щонебудь» [5, с. 171]; впитися - «міцно вхоплюватися, вчіплюватися» [5, с. 380]; Кинулася [мати] до Ганнусі I в коси впилася (Т. Шевченко); впертися - «силою, без дозволу заходити до якогось приміщення і т. ін..» [5, с. 381]; A далі вперлися в будинки Підземного сього царя (І. Котляревський); вп 'ястися - «не відводячи очей, дивитися на кого-, щонебудь» [5, с. 380]; Гальорка вп 'ялася очима в панів... (С. Васильченко).

Не менш продуктивним для вираження градуального значення $\epsilon$ префіксально-постфіксальний формант об- (обі-) + -ся. Він надає дієсловам значення «вияв дії впродовж певного часу 3 великою інтенсивністю». Лексеми обжертися, обсунутися, обідратися, обіжратися у своїй семантичній структурі мають спільну сему «занадто». Наприклад, обжертися означає «надмірно наїдатися, завдаючи шкоди своєму здоров'ю; об'їдатися» [5, с. 393]; - Нічого йому не станеться... - меду обжерся, тепер болить живіт... (С. Васильченко); обіжратися «надмірно напиватися (горілки, вина і т. ін..)» [5, с. 393]; В ией день отець опрягся, Як чикилдихи обіжрався (І. Котляревський); обсунутися «обсипатися, обвалюватися, руйнуючись під дією яких-небудь сил (про земляні споруди, схили і т. ін.)» [5, с. 423]; Обсунулась стара гребля, Місток похилився (С. Руданський); обідратися - «порвати, зносити до краю свій одяг; обноситися, обірватися» [5, с. 388]; - Чи бачиш, як ми обідрались! - Убрання, постоли порвались (І. Котляревський).

Значення дії, у яку виконавець повністю занурюється, захоплюється й стомлюється, передає префікс за- і постфікс -ся, утворюючи дієслова 
доконаного виду. Вищевказаний формант, виконуючи градуальну функцію, вносить у семантичну структуру дієслів гранд-відтінок - надмірність виконання дії. Дієслова закохатися, замріятися, загордитися, задивитися, закохатися, задихатися, задуматися, закашлятися, заслухатися об'єднані спільною семою «надто» (більше від звичайної норми, міри). Наприклад, лексема закохатися означає «пройнятися почуттям кохання до когось» [5, с. 702]; замріятися - «заглибитися, поринути в щось, задуматися над чимось» [5, с. 712]; загордитися - «стати гордовитим, чванливим; зазнатися» [5, с. 693]; задивитися - «захоплено, із замилуванням довго дивитися на когось, щось, кудись, у щось; заглядатися» [5, с. 695]; задихатися - «дихати часто, посилено, важко через утому, хвилювання та ін.» [5, с. 695]; задуматися - «зосереджено думати, розмірковувати над чимось, про когось» [5, с. 696]; закашлятися «заходитися кашлем, сильно і довго кашляти» [5, с. 700]; заслухатися «захоплюватися, забувати про інше, слухаючи щось, когось» [5, с. 724].

Словотворчий формант роз- (розі-) + -ся вносить у семантичну структуру дієслів значення «вияв дії, яка в результаті досягається поступовим наростанням інтенсивності», а отже, $\epsilon$ засобом вираження градуальності. Лексеми розбігатися, розбуиуватися, розгорітися, розгулятися, розігрітися, розпалитися, розпаскудитися, розговоритися з вищевказаним формантом об’єднані спільною семою «над міру». Наприклад, лексема розбігатися означає «почавши бігати, захопитися, ввійти в азарт» [5, с. 143]; Не гадай, шо $і$ з кіньми так легко даси собі раду. Полум'я мають у грудях, крізь ніздрі його видихають. Ледве й самому мені покоряються, як розбіжсаться (М. Зеров); розбуиуватися - «ставати бурхливим, неспокійним (про море, річку і т. ін.)» [5, с. 145]; Море було так розбушувалось від часу виїзду тьоті Елі, щуо тільки сьогодні встановилось (Леся Українка); розгорітися - «приходити у стан сильного збудження, душевного піднесення» [5, с. 156]; Мотря стоїть коло печі, та в зачіпку колупає... Почервоніла, розгорілася, щее кращза стала, ніж була (П. Мирний); розгулятися - «починати діяти, повністю проявляючи себе в чомусь» [5, с. 157]; До Хіврі сікався [Солопій], за макогін хватався; I не на жарттаки, сердега, розгулявся (Гулак-Артемовський); розігрітися - «нагріваючись, ставати теплим, гарячим» [5, с. 160]; Потік тухольський периий раз відроду побачив такий блиск; периий раз розігрівся в своӥм холоднім кам'янім ложі (І. Франко); розпалитися - «відчути сильний жар (перев. від хвороби)» [5, с. 179]; Скільки від них [обкладок] дітвори перемерло! Оце зранку любемиле бігає, дивись, в обід - розгорілося, розпалилося, на горлянку жаліється, а на другий день і Богові душу віддає... (П. Мирний); розпаскудитися «набути поганих нахилів, звичок» [5, с. 180]; Юруш розпаскудився на панстві, бо не брався й за холодну воду (І. Нечуй-Левицький); розговоритися «поступово захопившись розмовою, стати говірким, балакучим» [5, с. 154]; Він був чоловік поважний... Не многомовний, а коли вже розговориться, то () Ю. В. Ткаченко, 2013. 
паше [пашить] його кожне слово полум'ям (Марко Вовчок).

Префікс роз-, суфікс -ти- і постфікс -ся при творенні дієслів виконують градуальну функцію, оскільки вносять значення «початок дії» (нижче за норму). Лексеми розбігатися, розпочинатися, розпускатися, розгоратися, розганятися об'єднує спільна сема «злегка, у певній мірі». Наприклад, дієслово розбігатися означає «починати бігти» [5, с. 143]; розпочинатися - «проявляти перші ознаки» [5, с. 187]; Чудовий літній день розпочинався (Г. Хоткевич); розпускатися - «розвиваючись під дією тепла, сонячного проміння, ростучи, розпускатися, розкриватися (про бруньки, квіти, листя» [5, с. 189]; На землі в той дивний майський вечір розпускались мільйони рож, троянд (І. Нечуй-Левицький); розгоратися «починати горіти дедалі сильніше» [5, с. 155]; розганятися - «рухатися, поступово збільшуючи швидкість» [5, с. 152].

Дію, направлену на об’єкт сприйняття, передають префікс при- i постфікс -ся, приєднуючись до дієслівних лексем. Вони вносять у семантичну структуру слова значення інтенсивного вияву ознаки дії. Дієслова прислухатися, приподобитися, придиратися, притерпітися об'єднує спільна сема «дуже». Наприклад, лексема прислухатися означає «напружуючи слух, намагатися почути що-небудь» [5, с. 910]; Здалосяніби голос Марусин. Крикнула й замовкла. Прислухався - нічого не чути (Г. Хоткевич); приподобитися - «піддобрюватися» [5, с. 903]; [Юда] Учитель мав улюбленців між нами, - ми, зуби зціпивщи, їм догоджали, щуоб приподобитись йому хоч тим (Леся Українка); притерпітися «змиритися з чим-небудь» [5, с. 919], придиратися - «використовувати що-небудь як привід до якихось зауважень, обвинувачень (зазвичай безпідставних); прискіпуватися» [5, с. 884]; Усе придирається [Харко]: «У вас, каже, не так усе, як у людей» (Гр. Квітка-Основ’яненко).

Дієсловам притулитися, присмоктатися, причаїтися, притамання градуальність, оскільки вони передають значення одноразової дії 3 великою інтенсивністю. Вищезазначені дієслова об'єднані спільною семою «надто»: притулитися - «тісно присуватися, пригортатися до кого-, чогонебудь; горнутися» [5, с. 922]; Щось стало між нами. Я не смів притулитись до материних грудей, обняти сестру (М. Коцюбинський); присмоктатися - «прилипати, щільно приставати до кого-, чого-небудь за допомогою присосків» [5, с. 910]; причаїтися - «завмирати, тамуючи подих; затихати» [5, с. 7]; Кинулась [Гаӥнка] на ліжкові, підвелась $i$ впала знову, причайлася, затаӥвии й духа (Б. Грінченко).

Отже, градуальну семантику дієслів на словотвірному рівні в українській мові реалізують зазначені вище префіксально-постфіксальні форманти. Вони, приєднуючись до дієслівних лексем, вносять у їх семантичну структуру значення міри і ступеня. Префіксально-постфіксальні форманти виконують функцію градуаторів, а тому є засобом вираження градуальності в українській мові. 


\section{Література}

1. Добрушина Е. Р. Русские приставки: многозначность и семантическое единство : сб. ст. / Е. Р. Добрушина, Е. А. Меллина, Д. Пайар. - М. : Русские словари, 2001. - 270 с.

2. Ільїн В. С. Префікси в сучасній українській мові / В. С. Ільїн. - К. : Вид-во АН УРСР, 1953. $-167 \mathrm{c}$.

3. Исаченко А. В. Грамматический строй русского языка в сопоставлении с словацким : Морфология / А. В. Исаченко. - М. : Языки слав. к-ры, 2003. - 880 с.

4. Колесникова С. М. Категория градуальности в современном русском языке : дис. ... д-ра филол. наук : 10.02.01 / С. М. Колесникова. - М., 1999. - 421 с.

5. Тлумачний словник української мови : у 3-х т. / [авт.-уклад. В. Яременко, О. Сліпушко]. - К. : Аконіт, 2004. 